Ritrýnd grein birt 31. desember 2020

\title{
Skipulagið er komið út í bílskúr: Fjölskyldulíf, heimanám og COVID-19
}

\author{
Annadís Greta Rúdólfsdóttir og Auður Magndís Auðardóttir
}

Abstract

Um höfunda

About the authors

Heimildir

Markmið pessarar rannsóknar var að greina kynjaðar hugmyndir pátttakenda um uppeldishlutverk foreldra sem birtast í sögum um heimanám barna á tímum COVID-19. Gögnum var safnað með sögulokaaðferð í apríl 2020, en pá hafði neyðarstigi verið lýst yfir á Íslandi. Pátttakendur fengu upphaf að sögu sem peir áttu að ljúka. Par var söguhetjan ýmist móðir eða faðir sem purfti að sinna heimanámi með börnum sínum í samkomubanni. Auglýst var eftir pátttakendum á samfélagsmiðlum. Meirihluti peirra sem tóku pátt voru menntaðar millistéttarkonur og endurspeglar rannsóknin pví einkum sjónarhorn peirra. Alls voru 97 sögur greindar með ígrundaðri pemagreiningu. Fræðilega sjónarhornið var femínískt, p.e. pemu voru sett í samhengi við ríkjandi orðræður um foreldrahlutverkið í samtímamenningu og skoðað hvernig kynjuð hlutverk afmörkuðu tækifæri og forgangsröðun sögupersóna. Í sögunum var einkum tekist á við orðræðu nýfrjálshyggjunnar um skipulagða foreldrið sem nýtir hvert tækifæri til að hámarka reynslu barnsins svo pað verði skilvirkur pegn samfélagsins. Prjú meginpemu voru greind: (1) Togstreitan um tímann. Par kom fram að tíminn er kynjapólitísk auðlind. Verkefnamiðuð dagskrá krefst verkstjórnar og yfirlegu sem lenda oft á herðum mæðra. (2) Glíman við heimanámið: Endurmat og (ó)sigrar. Félagsleg staða, m.a. menntun og auðmagn, hefur áhrif á hversu raunhæfar forsendur foreldri hefur til að taka að sér heimanám. Kvíði og sektarkennd fylgir pví að ráða ekki við námsefnið. (3) Bugaðir foreldrar rísa upp gegn óraunhæfum kröfum. Pemað lýsir andstöðu foreldra við hamingjuhandrit nýfrjálshyggjunnar par sem gott foreldri er sér meðvitað um alla pá áhættupætti sem hafa áhrif á velferð barnsins. Hamingjuna má finna í heimilisóreiðu og námi sem fylgir ekki dagskrá skóla heldur takti heimilisins. Niðurstöður sýna að pær aðstæður sem sköpuðust í samkomubanninu skerpa átakalínur milli heimila og samfélags og átakalínur innan heimila. Pær lýsa einnig kvíða og sektarkennd sem fylgir pví að geta ekki fylgt leikreglum nýfrjálshyggjuorðræðunnar.

Efnisorð: Nýfrjálshyggja, foreldrahlutverkið, COVID-19, sögulokaaðferð

\section{Inngangur}

Markmið pessarar rannsóknar var að greina kynjaðar hugmyndir pátttakenda um uppeldishlutverk foreldra í sögum um heimanám barna á tímum COVID-19. Gögnum var safnað með sögulokaaðferð á tímabilinu 7. til 24. apríl en pá hafði neyðarstigi verið lýst yfir á Îslandi vegna kórónuveirunnar. Á pessum tíma voru íslenskar barnafjölskyldur undir miklu álagi. Samkomubann hafði verið sett á og miðað við að ekki mættu fleiri en 20 manns koma saman. Foreldrar með börn á leik- og grunnskólaaldri gátu margir hverjir ekki sent börn sín í skóla og voru foreldrar hvattir til að aðstoða börn sín með nám og skólaverkefni heima við. Ekki bætti úr skák að brýnt var fyrir landsmönnum að einstaklingar eldri en 50 ára væru í meiri hættu en aðrir að fá alvarlega sýkingu (www.covid.is) og pví erfitt fyrir pá foreldra sem purftu einnig að sinna vinnu að biðja ömmu og afa að gæta barna og sinna heimanámi peirra. Fyrst og fremst starfsmenn í framlínustörfum fóru til vinnu utan heimilis en aðrir reyndu eftir megni að sinna starfi sínu heiman frá og jók pað álagið á fjölskyldur. 
Fræðilegt sjónarhorn rannsóknarinnar er femínískt en við höfðum áhuga á að skoða pær orðræður sem móta hvernig foreldrahlutverkið er skilgreint. Við höfðum pá einkum áhuga á að skoða hvernig pessar orðræður skilgreina hlutverk mæðra og feðra og hvernig pær hugmyndir tengjast valdakerfum samfélagsins. Við höfum í annarri grein rakið pær kynjuðu myndir sem foreldrahlutverkið tók á sig í pessum sögum (Auður Magndís Auðardóttir og Annadís G. Rúdólfsdóttir, 2020) og togstreituna milli heimilis og vinnu sem birtist par. Við munum í pessari grein halda peirri greiningu áfram en pá einkum út frá sögum pátttakenda um hlutverk foreldra við að sinna heimanámi barna á „fordæmalausum“ tímum. Meginrannsóknarspurningin er: Hvaða hugmyndir um uppeldishlutverk mæðra og feðra og heimanám barna birtast í sögum um fjölskyldulíf á tímum COVID-19? Sem fyrr greinum við gögnin með kyngervisgleraugun á nefinu en skoðum einnig afdrif söguhetjanna út frá peirri félagslegu stöðu, t.d. hjúskaparstöðu, sem pær eru settar í í sögunum.

Í alpjóðlegri umræðu um íslenskt samfélag er mikil áhersla lögð á pann árangur sem náðst hefur til að jafna stöðu kynjanna og má segja að hugmyndin um jafnrétti kynjanna hafi orðið eins konar vörumerki fyrir Ísland (Porgerður J. Einarsdóttir, 2020). Hið „fordæmalausa ástand“ sem skapaðist í íslensku samfélagi meðan á neyðarstiginu stóð opinberaði pó átakalínur innan heimila og milli heimila og samfélags. Pær málamiðlanir og lausnir sem pátttakendur settu fram í sögunum varpa ljósi á orðræður og hugmyndir um fjölskyldur og skyldur peirra gagnvart börnum í íslensku nútímasamfélagi. Pessi rannsókn er innlegg í pá umræðu.

Áður en við gerum rannsókninni skil ræðum við stöðu foreldra í nútímasamfélagi og síðan hvernig sú staða hefur haft mótandi áhrif á hvernig uppeldishlutverk peirra er skilgreint.

\section{Staða foreldra í neyslusamfélagi nútímans}

Pær orðræður sem íslenskar fjölskyldur hafa aðgang að eru um margt mótsagnakenndar. Kvennahreyfingar hafa síðustu áratugi lagt ríka áherslu á að konur fái sömu tækifæri til að mennta sig og fóta sig á vinnumarkaðinum og karlar. Niðurgreiddir hágæða leikskólar og samfelld skólaganga barna er einn afrakstur peirrar baráttu og hafa gert mæðrum kleift að stunda launavinnu af peim krafti sem pær gera nú. Á Íslandi eru flestir foreldrar útivinnandi og á pað hefur verið bent að íslenskar konur vinna utan heimilis að meðaltali fleiri klukkustundir á viku en karlar í nágrannalöndum, t.d. Noregi og Bretlandi (OECD, e.d.). Á hinn bóginn búa íslenskar fjölskyldur í neyslusamfélagi sem hyglir orðræðu nýfrjálshyggjunnar. Nýfrjálshyggja er hér ekki eingöngu skoðuð sem stjórnmálaskoðun heldur sem hugmyndafræði og stjórnvaldstækni sem gegnsýrir daglegt líf alls fólks, í pað minnsta í auðugri ríkjum heims (Oksala, 2013; Rose, 1989). Stjórnvaldstækni nýfrjálshyggjunnar leggur áherslu á skyldu einstaklingsins til að gera sér sem mestan mat úr peim tækifærum sem eru til staðar. Staða fólks í samfélaginu er pá skýrð með pví að vísa í upplag og vinnu einstaklingsins sem hefur lagt sig fram um að nýta sér öll möguleg tækifæri til að styrkja sjálfan sig. Póstfemínískar hugmyndir eru afsprengi nýfrjálshyggjunnar en póstfemínistar halda pví fram að búið sé að ná jafnrétti í samfélaginu og pví sitji allir við sama borð (McRobbie, 2009; Walkerdine, Lucey og Melody, 2001). Slíkar hugmyndir hafa einnig skotið rótum hérlendis (Guðný Gústafsdóttir, 2016; Gyða Margrét Pétursdóttir, 2009). Áhersla er lögð á að nútímapegn sé sveigjanlegur og vakandi fyrir tækifærum (Skeggs og Wood, 2012). Hann er stöðugt að bæta sig í vinnu og heima fyrir auk pess að huga að hugarfari og útliti. Ein af leiðum stjórnvaldstækni nýfrjálshyggjunnar til að hafa áhrif á daglegt líf okkar er í gegnum orðræðu um tíma; með pví að skilgreina hvað telst góð tímastjórnun, hvað telst tímasóun og hvernig við ættum að verja tíma okkar á skilvirkan hátt. Petta á ekki eingöngu við um pátttöku í atvinnulífi eða skólastarfi. Stjórnvaldstækni nýfrjálshyggjunnar beitir nú einnig orðræðum um að rétt tímastjórnun í okkar persónulega lífi og innan heimilisins sé lykillinn að hamingjunni (Binkley, 2014). Dessar áherslur hafa átt greiða leið inn í skilgreiningar og umfjöllun um foreldrahlutverkið par sem áherslan verður á foreldri sem framkvæmdastjóra og ofurskipulagðan neytanda sem ber ábyrgð á að velja besta skólann, hverfið, tómstundirnar, vinina og námsefnið fyrir barnið (Ball, Bowe og Gewirtz, 1996; Byrne, 2006; Olmedo og Wilkins, 2016). Hérlendis sjást pess einnig merki að foreldrahlutverkið feli nú í sér virkt val á grunnskóla og hverfi til að ala börn 
upp í (Auður Magndís Auðardóttir og Kosunen, 2020; Auður Magndís Auðardóttir og Berglind Rós Magnúsdóttir, 2020; Berglind Rós Magnúsdóttir, Auður Magndís Auðardóttir og Kolbeinn Stefánsson, 2020). Pessi orðræða er mjög kynjuð en pað er einkum hin góða og hæfa móðir sem er talin bera ábyrgð á uppeldi framtíðarpegna samfélagsins (Lee, Bristow, Faircloth og Macvarish, 2014; Reay, 1998; Walkerdine og Lucey, 1988). Pessi orðræða hyglir efri stéttar mæðrum sem hafa fleiri tækifæri til að uppfylla pessar auknu kröfur, t.a.m. með pví að kaupa aðstoð við heimilishald. Mæður af verkalýðsstétt sem ekki hafa sama aðgang að upplýsingum og auðlindum til að takast á við pessar kröfur nýfrjálshyggjunnar eiga pá á hættu að vera skilgreindar sem frávik og óhæfar mæður sem sýna velferð barna sinna ekki áhuga (Gewirtz, 2001; Gillies, 2007; Rose, 1989).

Á Íslandi hefur orðræðan um hið meinta jafnrétti glapið sýn á hversu sterk tök kynjaðar orðræður hafa á hlutverki foreldra (Gyða Margrét Pétursdóttir, 2009). Pó svo að karlar séu farnir að axla meiri ábyrgð á heimilinu og ungir karlar séu farnir að endurskilgreina karlmennskuna út frá föðurhlutverkinu (Ásta Jóhannsdóttir, 2018) ætlast samfélagið enn til pess að konur axli meginábyrgð á barnauppeldi og heimilishaldi (Gyða Margrét Pétursdóttir, 2009). Rannsóknir par sem menntaðar konur með góðar stöður í fyrirtækjum hafa verið í forgrunni sýna að pær eru undir meira vinnuálagi en karlar heima fyrir og hafa minni stjórn á tíma sínum (Ólöf Júlíusdóttir, Guðbjörg Linda Rafnsdóttir og Porgerður J. Einarsdóttir, 2018; Guðbjörg Linda Rafnsdóttir og Ólöf Júlíusdóttir, 2018). Sams konar niðurstöður koma fram í nýlegri rannsókn á einstaklingum með doktorsgráðu á Íslandi (Staub og Rafnsdóttir, 2020). Pessar rannsóknir sýna að menntaðar konur sem eru að reyna að ná starfsframa samhliða pví að vera mæður eru undir meira vinnuálagi en karlar.

Orðræða nýfrjálshyggjunnar í nútíma vestrænum ríkjum beinir sjónum frá formgerð samfélagsins pegar leitað er lausna vegna pess mikla álags sem hvílir á mæðrum sem stunda launavinnu. Pannig leggur hugmyndafræði nýfrjálshyggjunnar áherslu á að við beitum einstaklingsbundnum lausnum við vanda sem er í raun kerfislægur (Cabanas og Illouz, 2019). Hún hefur pví svör á reiðum höndum um hvernig konur eiga að takast á við hið mikla vinnuálag. Fyrst og fremst eiga konur að vinna betur með sjálfar sig til að tryggja að pær verði ekki úrvinda. Orgid (2019) bendir á að í sjálfshjálparbókum og ýmiss konar bloggum sem einkum beinast að konum eru neikvæðar hugsanir og tilfinningar gerðar útlægar. Pess í stað eiga konur að einbeita sér að núinu og tileinka sér pakklæti og jákvæðar hugsanir. Viðbrögð kvenna við ópolandi álagi, preytan, vonbrigðin og pirringurinn, vekur pví vanlíðan peirra. Skilaboðin eru pau að pær hugsi ekki nógu vel um sjálfar sig, hugsi ekki „réttar“ hugsanir og pess vegna séu pær úrvinda. Pær eru hvattar til að bæta sig og proskast sem einstaklingar pví að sjálfsvinnan sé lykillinn að velgengni í samfélagi nútímans. Mæður eru sér einnig vel meðvitaðar um að peirra vinna geti skorið úr um velgengni barna peirra í skólanum og lífinu. Laura Berlant (2011) kallar pessa drauma um velgengni í nýfrjálshyggjusamfélagi nútímans andstyggilega bjartsýni (e. cruel optimism) pví að kerfislægar hindranir komi í veg fyrir að hamingjudraumarnir geti nokkurn tímann ræst. Pað á ekki hvað síst við um konur sem axla bæði ábyrgð sem mæður og vilja ná árangri á vinnumarkaðinum.

\section{Uppeldishlutverk foreldra eins og pað er skilgreint í samtímaorðræðum}

Í nútímasamfélagi hefur krafan um pátttöku foreldra í námi barna sinna aukist mikið. Petta á við um öll auðug ríki heims (Vincent, 2017), einnig Îsland (Kristín Jónsdóttir, 2013) og hin Norðurlöndin (Helgøy og Homme, 2017). Almennt virðast stefnumótandi aðilar á pessu sviði ekki gera sér grein fyrir hversu ójafnt pessi vinna skiptist á milli kynja og hvernig hún kemur ólíkt við fjölskyldur eftir stétt peirra og uppruna. Macvarish (2014) greindi hvernig uppeldisaðferðir foreldra og samskipti innan fjölskyldna hafa æ meir lent undir smásjá af ríkisvaldinu í Bretlandi. Foreldrar sem ekki pykja hafa sýnt nógu góða foreldrahæfni, t.d. vegna pess að börn peirra hafa skrópað í skóla, hafa verið skyldaðir á námskeið og hefur pað verið rökstutt með pví að verið sé að tryggja að peir ali ekki upp fleiri einstaklinga sem eru á skjön við lög og reglur samfélagsins (Macvarish, 2014). Pað kemur pví ekki á óvart að pátttakendur eru oftast lágstéttarmæður (Holloway og Pimlott-Wilson, 2014). Millistéttarmæður sem hafa meiri tekjur og menntun hafa forskot á konur úr lágstétt. Pær og fjölskyldur 
peirra hafa efni á að senda börnin sín á námskeið og borga fyrir aðstoð pegar pær geta ekki sinnt heimanámi barnanna sjálfar (Reay, 2017). Í pví samhengi er áhugavert að menntaðar heimavinnandi millistéttarmæður lýsa heimilishaldi eins og atvinnurekstri par sem pær eru framkvæmdastjórar (Orgid, 2019). Heimanám barnanna er pá eitt af verkefnum framkvæmdastjórans. Vinna mæðranna er bó ekki aðeins drifin áfram af metnaði fyrir að barninu gangi vel í skólanum heldur einnig af kvíða yfir að pær standi sig ekki í móðurhlutverkinu (Hutchison, 2012). Mikið liggur undir par sem pað er háð einkunnum barnanna hvort pau komast í góða skóla sem tryggja síðan að pau séu vel sett fyrir samkeppni á vinnumarkaði. Í vestrænum samfélögum, t.d. í Bretlandi, hefur bil á milli stétta verið að aukast sem pýðir að erfiðara er fyrir einstaklinga að færa sig upp um stétt (Reay, 2020).

Í vestrænum samfélögum hafa skilaboðin um hvernig beri að haga uppeldi barna verið tvíbent. Ýmist er lögð áhersla á hversu mikið aðhald og eftirlit börnin purfa; hins vegar er lögð áhersla á að foreldrar megi ekki vefja börnin sín í bómull, pví annars læri pau aldrei af mistökum sínum. Börn purfi líka að fá tækifæri til að læra á heiminn upp á eigin spýtur (Lee o.fl., 2014). Fyrir foreldra er petta vandratað einstigi. Fjölmiðlar flytja fréttir af peim mörgu hættum sem börnunum eru búin: Skjátími, kyrrseta og skyndibitar svo fátt eitt sé nefnt. Macvarish (2014) bendir einnig á að vanræksla og ofbeldi nái nú yfir fleiri pætti en áður, t.d. pykir pað dæmi um að foreldrar hafi brugðist ef holdafar barna fylgir ekki viðmiðum samfélagsins. Frank Furedi (2001) heldur pví fram að foreldrar í vestrænum samfélögum séu orðnir vænisjúkir, par sem peir tortryggi allt og hafi stöðugar áhyggjur af börnum sínum. Skólaferðalög eru slegin af par sem foreldrar óttast um öryggi barna sinna. Foreldrar, heldur hann fram, eru að missa kjarkinn pví peim finnst peir stöðugt vera að bregðast börnunum sínum. Peir eru pví pjakaðir af kvíða og sektarkennd.

Á sîðustu áratugum hefur kvíði foreldra ekki hvað síst snúið að skjánotkun barna. Rannsóknir benda til pess að sá kvíði hafi verið að aukast enda hefur tækni og efni sem börn hafa aðgang að breyst hratt (Livingstone, 2017; Livingstone og Sefton-Green, 2016). Sonia Livingstone (2017) bendir á að umhverfi barna sé í auknum mæli að verða stafrænt og tölvur gegni mikilvægu hlutverki í námi peirra og afpreyingu. Foreldrar hafa verið hvattir til að fylgjast vel með skjánotkun barna sinna og m.a. takmarka pann tíma sem pau hafa aðgang að hinum stafræna heimi. Livingstone (2017) bendir á að hömlur á aðgengi barna að tölvum og farsímum séu kannski ekki besta leiðin til að vernda pau heldur ætti að setja meiri ábyrgð á fyrirtækin og iðnaðinn sem hanna stafræna tölvuheiminn. Fyrirtækin eru í hvað bestri aðstöðu til að gera pann heim barnvænan og öruggan. Pað sé svo í hendi stjórnvalda að hafa eftirlit með pví að pau axli pá ábyrgð.

Foreldrar sinna ekki einungis barnauppeldi heldur bera yfirleitt einnig ábyrgð á heimilishaldi. Par hafa mæður yfirleitt axlað mesta ábyrgð. Verk sem parf að inna af hendi eru pví marki brennd að pau parf sífellt að endurtaka. Prif og eldamennska eiga sér stað daglega og umönnun einstaklinga í fjölskyldum er stöðug (Nathanson, 2013). Fjölskyldur purfa að komast að samkomulagi um verkaskiptingu, sérstaklega pegar báðir foreldrar eru útivinnandi. Pað er engin skortur á sérfræðingum sem bjóða lausnir sem auka skilvirkni og bæta skipulag. Svo dæmi sé tekið pá var starfsmönnum Háskóla Íslands, sem hafa verið undir miklu álagi vegna heimsfaraldursins, nýlega boðið að taka námskeið sem hafði pað að markmiði að „hjálpa til við að einfalda heimilisstörfin“ og gera pau „bæði einfaldari og skemmtilegri“" (tölvupóstur til starfsmanna 8. október 2020). Petta minnir óneitanlega á greiningu Binkley (2014) á hvernig hugmyndafræði nýfrjálshyggjunnar um skilvirka tímastjórnun sé nú einnig beint að persónulegu lífi fjölskyldna. Nathanson (2013) greindi vinsæla sjónvarpspætti par sem kenndar eru kerfisbundnar aðferðir til að takast á við óreiðu. Í peim má sjá hvernig gott skipulag og skilvirkni eru talin forsenda pess að fjölskyldumeðlimir geti slakað á og notið samverustunda. Heimilin lýsa með öðrum orðum fjölskyldunum sem par búa. Skilaboðin eru pau að óhamingjusamar fjölskyldur búi í óreiðu en hamingjusamar fjölskyldur í hreinum og vel skipulögðum híbýlum.

Færð hafa verið rök fyrir pví að nýfrjálshyggjuvæðing foreldrahlutverksins par sem foreldrar purfa að stöðugt að stýra barninu og velja pað besta fyrir pað skapi ómanneskjulegt álag á foreldra, einkum mæður (Cappellini, Harman, Marilli og Parsons, 2019). Раð ástand sem skapaðist vegna COVID-19 
er áhugavert með hliðsjón af pessum hugmyndum, par sem foreldrar purftu að sinna fjölskyldu sinni við breyttar aðstæður og takast á við hættulega veiru sem ógnaði heilsu og öryggi heimilisfólks. Auknar kvartanir til barnaverndarnefndar og fréttir um aukið heimilisofbeldi sýna að margar fjölskyldur áttu erfitt með að höndla petta álag (Barnaverndarstofa, 2020; Ingvar Pór Björnsson, 2020).

\section{Аðferð}

Til að safna gögnum í pessa rannsókn beittum við svokallaðri sögulokaaðferð (Auður Magndís Auðardóttir og Annadís G. Rúdólfsdóttir, 2020; Braun o.fl., 2019; Clarke, Hayfield, Moller og Tischner, 2017; Sólveig Sigurðardóttir og Annadís G. Rúdólfsdóttir, 2019). Aðferðin felur í sér að pátttakendur fá stutt upphaf að sögu sem peir eru beðnir um að ljúka. Peim eru ekki settar neinar skorður um hvernig peir skrifa sögurnar en eru beðnir um að skila inn ákveðnum lágmarksorðafjölda til að rannsakendur hafi efni til að vinna með. Sögurnar eru skáldskapur og pykja pær pví henta vel til að rannsaka viðkvæm málefni. Pátttakendur eru ekki beðnir um að lýsa eigin reynsluheimi og geta gert grein fyrir eldfimum eða viðkvæmum málefnum án pess að pau tengist persónu peirra. Sögurnar eiga sér pað pó allar sammerkt að byggja á hugmyndum sem pekktar eru í menningu og samfélagi pátttakanda. Pessi rannsókn snýr pví ekki að pví að meta sannleiksgildi sagnanna heldur greinum við pær hugmyndir og gildismat sem par koma fram (Braun o.fl., 2019).

Auglýst var eftir pátttakendum á Facebook. Auglýsingarnar voru birtar í vinsælum hópum með mörgum meðlimum, t.d. „Vinna með stuttum fyrirvar““ og „Allt gefins“. Pátttakendum var beint inn á rafræna síðu par sem peir fengu nánari upplýsingar um rannsóknina. Pátttakendur voru upplýstir um að ekki væri hægt að rekja svör til peirra; að peir hefðu rétt á að sleppa að svara spurningum og gætu dregið sig úr rannsókninni með pví að hafa samband við ábyrgðarmenn hennar. Nöfn peirra sem tóku pátt voru ekki tengd við sögurnar sem við greindum. Clarke og félagar (2017) benda á að pessi aðferð veki færri siðferðilegar spurningar en aðrar par sem pátttakendur eru ekki spurðir um persónulegt líf sitt. Gagna var einnig aflað með rafrænum hætti sem auðveldar pátttakendum að draga sig út úr rannsókninni ef peim finnst viðfangsefni hennar erfitt.

Pegar pátttakendur höfðu veitt upplýst sampykki og svarað bakgrunnsspurningum um hvernig peir skilgreindu kyn sitt, menntun og tekjur voru peir kynntir fyrir söguupphafinu.. Upphaf sögu og spurningar sem tengdust hvorri sögu voru eins nema í helmingi sagnanna hét sögupersónan Sigríður og í hinum hlutanum Ólafur.

Sigríður/Ólafur á tvö börn á grunnskólaaldri. Eftir að samkomubann er sett á fær hún/ hann tilkynningu frá skólanum um að pau fái aðeins tvær klukkustundir í skólanum annan hvern dag. Stuttu seinna senda umsjónarkennarar barnanna margar hugmyndir að verkefnum fyrir skólann sem pau geta unnið heima.

Lýstu næstu dögum í lífi Sigriððar/Ólafs. Pú getur haft pessar spurningar í huga ef pú vilt: Hvernig líður henni/honum? Hvernig líður börnunum? Hvað gerir hún/hann við verkefnin frá kennurunum? Á hún/hann maka? Hvernig gengur fö̈lskyldulífið fyrir sig? Er hún/hann í vinnu? Hvernig gengur að samræma vinnu og einkalíf?

Alls tóku 97 pátttakendur pátt í rannsókninni. Sögurnar voru mismunandi að lengd, allt frá 68 að 1461 orði. Heildarorðafjöldi af sögum sem voru greindar var 32.779 orð. Nokkur kynjahalli var meðal pátttakenda en $82 \%$ voru konur, $14 \%$ karlar og 3\% kynsegin. Meirihluti pátttakenda var með háskólamenntun eða 78\% og flestir eða 82\% á aldrinum 18-30 ára. Flestir eða 45\% bjuggu á höfuðborgarsvæðinu. Hér er pví fyrst og fremst um afmarkaðan hóp pjóðfélagsins að ræða, p.e. konur með háskólamenntun sem búa í Reykjavík og nágrenni og verður að hafa pað í huga við greiningu gagnanna. 
Til að greina gögnin notuðum við pemagreiningaraðferð sem próuð hefur verið af Braun og Clarke (2006). Pær hafa nýlega byrjað að vísa til pessarar aðferðar sem ígrundaðrar pemagreiningar (e. reflexive thematic analysis) til að skilja hana frá peim fjölmörgu og ólíku tegundum pemagreiningar sem eru til staðar (Braun og Clarke, 2020; Terry, Hayfield, Clarke og Braun, 2017). Einkum breyttu pær heitinu til að undirstinga að rannsakendur verði að huga vel að pví hvernig fræðilegt sjónarhorn og greining gagna fer saman (Braun og Clarke, 2020). Greiningin fól í sér að gögnin voru lesin vandlega með hliðsjón af rannsóknarspurningu og kóðuð. Kóðarnir voru vandlega yfirfarnir og peir kóðar flokkaðir saman sem vísuðu í svipaðar hugmyndir. Út frá peirri vinnu var komið með tillögu að pemum og pau skoðuð aftur út frá gögnunum áður en endanleg pemu voru sett fram. Í greiningunni lögðum við áherslu á að bera saman sögur par sem sögupersónan var karl eða kona og skoðuðum vel hvernig pemun tengdust orðræðum um foreldrahlutverkið og heimanám. Par sem fræðilega sjónarhornið var femínískt skoðuðum við einkum hvernig sú pekking sem vísað var í var kynjuð og einnig hvort félagsleg staða sögupersóna mótaði sögupráðinn og pá möguleika sem hún hafði til að sinna foreldrahlutverkinu. Pegar vitnað er í sögurnar í niðurstöðukaflanum er framsetningu pátttakenda fylgt eftir en textinn lagaður til pegar parf til pess að auðveldara sé að lesa hann.

\section{Niðurstöður}

Sögurnar ber að lesa með pað í huga að flestir höfundar peirra eru millistéttarkonur með háskólamenntun. Sá hópur er pó áhugaverður par sem hann er yfirleitt viðmiðið pegar rætt er um góða mæðrun.

Pátttakendur setja viðbrögð sögupersóna í samhengi við pann stuðning sem pær hafa aðgang að við að reka heimilið og sinna launaðri vinnu. Margir pátttakendur hafa kosið að skapa meiri spennu með pví að sleppa öðru foreldrinu í sögunum sem peir skrifa. Ýmist eru karlarnir ekklar eða konurnar fráskildar. Í mörgum sögum er maki gerður að starfsmanni í framlínustarfi sem gerir að verkum að hann getur ekki tekið pátt í heimilisstörfum og aðstoðað við heimanám. Pað var líka áhugavert hversu oft var minnst á að börnin væru með greiningar eða fötlun sem gerðu foreldrum erfiðara um vik að sinna heimanáminu.

Pemun sem við greindum voru: 1) Togstreitan um tímann, 2) Glíman við heimanámið: Endurmat og (ó)sigrar og 3) Bugaðir foreldrar rísa upp gegn óraunhæfum kröfum.

\section{(1) Togstreitan um tímann}

Einn af rauðu práðunum í gegnum sögurnar er umræða um tímann. Ýmist líður hann hægt og í leiðindum rétt eins og allir dagar mánaðarins væru „föstudagurinn langi“ eða foreldrar finna sárlega fyrir tímaskorti til að ná yfir öll verkefni dagsins, par með talið heimanámið. Söguhetjur sem upplifa petta tímabil sem langdregið og leiðigjarnt eru yfirleitt foreldrar sem eru heima en geta ekki sinnt vinnu sinni par. Sögupersónur sem purfa að sinna vinnu og börnum kvarta í sögunum yfir að skorta tíma og eiga erfitt með að sinna heimanámi barnanna.

Nathanson (2013) bendir á að tíminn sem foreldrar hafa til umráða sé eitt af stórum kynjapólitískum málum samtímans og sögurnar bera vitni um pað. Í sögunum eru pað einkum mæður sem eru í tímapröng en einnig einstæðir foreldrar af báðum kynjum. Heimanám barnanna meðan takmarkanir vegna COVID-19 voru í hámarki var hrein viðbót við pá vinnu sem foreldrar sinntu pegar. Margar sögur lýsa pessari viðbótarvinnu sem verulega ípyngjandi og óraunhæfri, sérstaklega pegar foreldri ætlaði að reka heimilið eins og pað væri skóli:

Núna voru tvær vikur liðnar af samkomubanninu og Sigga var búin að vera með heimaskóla alla dagana og reyna að halda peim við efnið. Рað var samt hægara sagt en gert. Ekki nóg með að hún pyrfti að vera heima allan daginn og vinna auk pess að sinna tvíburunum með öllu pví drasli og havaríi sem pví fylgdi heldur purfti hún núna að vera heima með pétta 
dagskrá fyrir pau pann tíma sem pau voru ekki í skólanum sem hún pyrfti sjálf að taka pátt í miklu leyti. Petta hefði kannski ekki verið svo slæmt ef ekki hefði komið póstur frá ípróttafélaginu um að núna yrðu send æfingavídeó sem öll fjölskyldan gæti tekið pátt í og frá tónlistarskólanum að pað yrði fjarkennsla. Allt petta á vinnutíma.

Sögurnar lýsa hvernig pessar auknu kröfur til foreldra kalla á yfirlegu og skipulag sem oftast lendir á herðum móðurinnar. Nýta parf hverja mínútu vel, móðirin parf að vera paulskipulögð en um leið ógnar „drasl og havarí“ pví að slíkt verði að veruleika. Petta pema tengist skilaboðum nýfrjálshyggjuhugmynda um að skilvirk tímastjórnun eigi ekki aðeins við í atvinnulífi og skóla heldur einnig inni á heimilum okkar (Binkley, 2014). Pessar niðurstöður eiga sér einnig samhljóm með niðurstöðum úr rannsókn Andreu Hjálmsdóttur og Valgerðar S. Bjarnadóttur (2020) sem greindu dagbókarskrif íslenskra mæðra meðan á samkomubanni stóð vorið 2020. Par kom í ljós að iðulega lenti pað á herðum mæðra að verða eins konar verkstjórar með yfirsýn á nýtingu tímans og að skipuleggja vinnu annarra á heimilinu. Í eftirfarandi sögubroti er móðirin einmitt verkstjóri með yfirsýn á skipulag dagsins en axlar um leið ábyrgð á að heimanámið eigi sér stað. Hún kann að nýta tímann og bæði nær skikki yfir heimanám barnanna og nær að sannfæra föðurinn um að hann purfi líka að leggja sitt af mörkum:

Sigga hefur tamið sér að vera skipulögð og sér fljótlega að pað purfi að búa til skýran ramma um heimavinnu barnanna og eins verkaskiptingu peirra hjónanna. Hún leggur pví fyrir Nonna manninn sinn drög að skipulagi par sem börnin vinna heimavinnuna sem sett var fyrir frá kennurum peirra og skiptir á pau hjónin umsjón með heimavinnunni. Nonni er ekki spenntur par sem hans hluti af umsjón með börnunum verður að vera eftir hans vinnudag. Sigga bendir honum á að hún sé enn að vinna fullan vinnudag og jafnvel meira en venjulega par sem fjarkennslan krefst viðbótarskipulags og stundum að umturna kennsluáætlunum og endurskapa. Pau ná að ræða um málið og sættast á að pau verði að gera pað besta í peim óvenjulegu aðstæðum sem eru uppi.

Í textabrotinu á undan og nokkrum öðrum sögum er pví lýst hvernig tíminn verður bitbein foreldra. Góð tímastjórnun gerir ekki aðeins heimanám mögulegt heldur getur bjargað sambandi foreldra. Textabrotið sýnir einnig hvernig tími móðurinnar togast á milli húsverka og launaðrar atvinnu - og í miðjunni stendur eiginmaðurinn Nonni sem ekki áttar sig á pessari togstreitu sem Sigga upplifir. Femínískt fræðafólk hefur enda löngum bent á ósýnileika húsverka og hvernig pau eru í eðli sínu endurtekningasöm og einhæf (Nathanson, 2013). Í textabrotinu hér að ofan má segja að skilningsleysi Nonna byggi einmitt á pessari sýn á húsverk. Pannig afhjúpar sagan fátið (e. panic) sem einkennir líf kvenna sem purfa að skipta tíma sínum á milli húsverka og atvinnu (Nathanson, 2013). Um leið snýr sagan einnig að pirringi mæðra í garð feðra sem peim finnst ekki vera að standa sig (Auður Magndís Auðardóttir og Annadís G. Rúdólfsdóttir, 2020). Undirliggjandi ádeilu á feður sem ekki axla ábyrgð má sjá í nokkrum sögum:

Hann hefur alltaf verið „skemmtilegi pabbinn“ sem er meiri félagi en uppalandi. Seinasta vetur hefur hann purft að taka meiri ábyrgð á uppeldi sona sinna sem gengur hálfbrösulega par sem hann á erfitt með að hafa yfirsýn yfir allt sem parf að gera. Hann vorkennir sjálfum sér og nennir pessu ekki.

Sögurnar lýsa hvernig góðir foreldrar forgangsraða tíma sínum börnunum í hag og í sumum sögunum er pví lýst hvernig launaða vinnan er látin víkja fyrir pörfum heimilisins:

Sigríður vekur börnin á slaginu sjö alla daga meðan á samkomubanni stendur. Hún verður auðvitað að halda öllu í röð og reglu enda eru blessið börnin viðráðanlegri, ja eins og við öll, ef haldið er í ákveðna rútínu á pessum viðsjárverðu tímum. [...] Sigríður er reyndar löngu búin að fatta að pað er eiginlega ekki hægt að vinna í fjarvinnu með börnin heima. Pess vegna hefur hún ákveðið að nýta pennan tíma til gæðastunda með börnunum eftir að pau hafa lokið við heimanámið. 
Sigríður er í sögubrotinu hér að ofan einstæð móðir sem á að sinna fjarvinnu heima en öðlast ekki ró og hamingju fyrr en hún hættir að vinna á vökutíma barnanna. Tíminn með börnunum eru "gæðastundirnar". Sagan kristallar bæði togstreituna um tímann á milli barnauppeldis og atvinnu en líka hversu mikilvægt er að hin hæfa móðir sé öguð og skipulögð, vakni á slaginu klukkan sjö á hverjum morgni og haldi öllu í röð og reglu. Pá nýtir hún tímann einnig til fulls en hér í págu barnanna, hún forgangsraðar peim fram yfir atvinnu sína. Atvinnunni er ýtt út á jaðar dagsins, eftir að húsverk og börn hafa fengið forgang. Togstreitan um tíma mæðra (Nathanson, 2013) er leyst með ögun og skipulagningu. Tíminn sem fer í að vinna með börnum heima tekur pví sinn toll. Tíminn er ekki ótakmörkuð auðlind og sögurnar undirstrika hversu nærri sér söguhetjan gengur til pess að tryggja að börnin geti lært heima:

Til pess að bregðast við pessum nýja veruleika forgangsraðar hún pannig að hún mætir í tímana sína á netinu og hjálpar börnunum með peirra heimanám yfir daginn. Hún reynir að fara út með börnin einu sinni á dag, í göngutúr eða á leikvöll. Dagurinn er rammaður inn með máltíðum sem eru nokkurn veginn á sama tíma milli daga, önnur rútína er ekki uppi á teningnum. Eigið heimanám Sigríðar mætir afgangi pangað til börnin eru sofnuð. Hún vinnur oft fram á nótt og missir svefn.

Báðir foreldrar axla pessa ábyrgð en mæður eru pó meira áberandi í pessu hlutverki. Fjölskyldu- og heimilislífið verður nánast eins og excel-skjal par sem öll verkefni eru færð inn og allt á sér sinn stað. Hvert verkefni hefur sér markmið og pví minni tími sem foreldrið hefur, pví hraðara verður pað að vinna verkefnið. Petta skapar kvíða og foreldrið lætur eigin parfir sitja á hakanum. Nathanson (2013) vísar í petta sem póstfemíníska jafnvægislist. Með pví á hún við að í samfélagi póstfemínisma, par sem við teljum okkur trú um að jafnrétti hafi verið náð og konur eru virkar í atvinnupátttöku, séu mæður um leið undir gríðarlegum prýstingi um að halda mörgum boltum á lofti samtímis. Pannig líti póst-femínísk hugmyndafræði framhjá peim tilfinningalega kostnaði sem konur bera af pví að purfa að bera ábyrgð bæði á heimilishaldi og atvinnu (Walkerdine o.fl., 2001). Við sjáum pað í sögunum að pær fjalla meðal annars um pennan tilfinningalega kostnað, söguhetjan Sigríður missir pannig svefn og er áhyggjufull og kvíðin.

Par sem aðalsöguhetjan er höfð einstæð skiptir pað miklu máli til að allt gangi vel heima fyrir að hún sé skipulögð. Deginum er skipt upp í minni tímaeiningar sem eru eyrnamerktar mismunandi verkefnum, m.a. heimanámi, sem parf að leysa. Skilvirknin og skipulagið sem Nathanson (2013) benti á eru hér til fyrirmyndar og hvort tveggja er talið til kosta góðra mæðra:

Sigríður kemst að pví að pað er ekki tekið út með sældinni að sinna starfi sínu ásamt pví að hjálpa börnunum við heimanámið og láta heimilislífið ganga eðlilega fyrir sig. Petta tekst pó pokkalega pví Sigríður er skipulögð og byrjar að vinna eldsnemma á morgnana á meðan börnin fá að sofa út. Hún er vön að byrja daginn snemma pví fyrir samkomubann var hún vön að fara í ræktina kl. sex á morgnana. Um tíuleytið, pegar börnin eru vöknuð og búin að fá sér morgunmat, er Sigríður búin að ná fjögurra tíma vinnu og tekur sér pásu til pess að halda börnunum að verki við heimanámið.

Ólafur elskar að eyða tíma með börnum sínum, en er hræddur við að verða stressaður og að pað hafi slæm áhrif á fjölskyldulíf peirra. Ólafur getur unnið heima en makinn getur pað ekki. Honum finnst mjög gott að vera virkari í skólalífi barnanna en hann fattar að hann getur ekki unnið pegar börnin eru líka heima. Hann getur pá ekki einbeitt sér og hann verður stundum reiður út af pví. Hann reynir að búa til áætlun fyrir fjölskylduna, til að ná að vinna á daginn og ekki bara um kvöldin. Hann reynir að sannfæra makann að hjálpa til í húsinu og með börnin en petta er mjög erfitt. Honum finnst hann vera mjög einn stundum en líst vel að á að vera nánari börnunum.

Eins og sjá má af seinna sögubrotinu glímdi Ólafur stundum einnig við togstreitu um tímann. Pað vekur athygli að í peirri sögu er óljóst af hvaða kyni makinn er. Ólafur nýtir tímann til hins ýtrasta og reynir að forgangsraða börnunum fram yfir atvinnu sína. Parna skapar tímaleysið um leið togstreitu á milli sambúðaraðilanna. 
Á heildina litið sjáum við að togstreitan um tímann er viðvarandi práður í gegnum sögur pátttakenda. Togstreitan birtist bæði á milli heimilis og atvinnu og á milli foreldra. Einkum virðist mæðrum vera lýst pannig að pær búi við pessa togstreitu en pó eru dæmi um að Ólafur upplifi einnig kvíða og streitu vegna tímaskorts. Sögurnar gefa tilefni til að álykta að hvernig heimilisfólk, einkum mæður, verji tíma sínum, sé algengt bitbein í nútímafjölskyldum (Nathanson, 2013). Pað er ekki síst mikilvægt að greina pað og skilja nú á tímum kreppu, heimsfaraldurs og aukins álags á heimilum landsins.

\section{(2) Glíman við heimanámið: Endurmat og (ó)sigrar}

Petta pema lýsir hvernig söguhetjunum finnst pær knúnar til að skilgreina og jafnvel endurskilgreina hlutverk sitt í menntun barnanna; ýmist ganga foreldrar inn í hlutverk kennarans eða ákveða að slaka á kröfum um heimanám. Tvennt virðist skipta máli pegar kemur að pví hversu vel foreldri gengur að sinna heimanámi barna. Annars vegar að foreldri purfi ekki að sinna launaðri vinnu á sama tíma og heimanámið á sér stað. Mikið álag hefur neikvæð áhrif á geðheilsu foreldris og skapar kvíða og sektarkennd. Hins vegar að pað hafi pekkingu/menntun til að taka að sér heimanámið. Pemað opinberar hversu miklu máli félagsleg staða foreldris skiptir og hvort pað hefur raunhæfar forsendur til að taka að sér heimanámið.

Sögurnar lýsa pví að pegar ekki parf að sinna vinnu heima fyrir gengur heimanámið ágætlega. Ýmist setja foreldrarnir upp eins konar skólastofu á heimilinu eða gera námið hluta af samverustund fjölskyldunnar. Samverustundirnar pjóna pá markmiðum námsins:

Pau fara í göngutúra um hverfið og skoða náttúruna - pað er nefnilega skóli líka - og oftar en ekki baka pau saman, spila, púsla og njóta samverunnar.

Pegar vel tekst til lýsa sögurnar ánægju söguhetjunnar. Hún hefur náð að tengjast börnunum sínum betur og nýtur samverustunda með peim. Í peim sögum má oft einnig greina andóf gegn löngum vinnudegi foreldra og peirri péttu dagskrá sem venjulega einkennir líf fjölskyldunnar. Pær sögur eiga sér samhljóm með ýmsum rannsóknum sem gagnrýna jafnvægið milli vinnu og heimilis í nútímasamfélagi par sem mæður vinna fulla vinnu en axla meiri ábyrgð heima en karlar (Ólöf Júlíusdóttir o.fl., 2018; Guðbjörg Linda Rafnsdóttir og Ólöf Júlíusdóttir, 2018). Breyttar aðstæður vekja foreldra til umhugsunar um hvernig heimilislífið gæti verið. Hin stífa dagskrá sem einkenndi fjölskyldulífið fyrir COVID-19 er kannski ekki af hinu góða. Með meiri tíma gefast tækifæri til að verja tíma með börnunum, m.a. við heimanámið.

Krakkarnir vildu teikna og föndra, fara út að leika, fara að finna bangsa í göngutúr og gefa öndunum að borða. Foreldrarnir nýttu svo hugmyndir kennara til að vinna að á milli pess sem krakkarnir vildu helst gera. Fjölskyldunni leið vel á pessum tímum og töldu að petta gerði samband peirra á milli enn sterkara en pað var fyrir tíma Covid.

Hlutirnir sem enginn í fjölskyldunni hafði áður orku í - langur vinnudagur hjá Sigríði og enn lengri dagur hjá börnunum með skóla, frístund, tónlistartímum og ípróttum fram eftir degi. Pegar heim var komið tók við úlfatími, allir preyttir og pirraðir. Covid hefur svolítið læknað petta, fátt er svo með öllu illt.

Eins og sjá má í textanum hér að ofan felur pað að gera heimanám hluta af samverustund fjölskyldunnar oft í sér endurmat á pví í hverju nám getur falist. Skipulagt heimanám er lagt á hilluna og/eða nám er endurskilgreint og felst nú ekki lengur í hefðbundnum lærdómi á forsendum skólans. Pær sögur virka sem ádeila á hugmyndina um að skilvirk og vel skipulögð heimili sem taka pátt í starfi skólans séu forsenda hamingjunnar (sjá Nathanson, 2013). Pess í stað er nám barnanna endurskilgreint út frá forsendum heimilisins og óskum barnanna. Nám barnanna getur jafnvel falist í tölvuleikjaspili, borðspilum með fjölskyldunni eða að fletta gömlum ljósmyndaalbúmum. Börnin og foreldrarnir eru hamingjusamari pegar pau fá að ráða sínum tíma sjálf - óháð ytri kröfum samfélagsins og skólans. Fleiri dæmi eru í sögunum um að hefðbundið bóknám, á forsendum skólans, 
sé gagnrýnt og pví úthýst. Hér koma pó einnig fram hugmyndir um að börnin purfi stöðugt áreiti sem eflir proska peirra og að móðirin líti á pað sem sitt verkefni að skapa slíkt umhverfi. Petta er í samræmi við nýfrjálshyggjuhugmyndir um að pað sé í verkahring mæðra að pjálfa börnin sín í að verða fyrirmyndarpegnar. Samverustundin er verkefnamiðuð og með markmið sem pjónar tilgangi námsins (Walkerdine o.fl., 2001). Að slæpast er ekki af hinu góða:

Krakkarnir fengu áætlanir og heimaverkefni frá kennurum sínum og frekara heimanám gekk illa að motivera pau til að sinna. Peim gengi vel og voru nánast of snögg að klára, pað var svo vont að hafa pau aðgerðalaus að slæpast. Hún endaði með að prenta verkefnahefti út af netinu með óvenjulegum verkefnum sem reyndu á ýmsa færni og hún vonaði að væru skemmtileg. Síðan fann hún til hlekki á 'virtual' safnaferðir og annað menningar-og listaefni sem nú var aðgengilegt og setti upp hóflegt húsverkaplan. Planið var að láta pau sinna smá verkefnum og smá húsverkum á hverjum degi og vona svo að frelsið skilaði sér í grúski og brasi sem pó væri uppbyggilegt a.m.k. að einhverju leyti. Óhefðbundið nám, pað er dýrmætt líka.

Pó eru einnig dæmi um að óhefðbundið nám og uppbrot á skólaverkefnum sé aðeins gert mögulegt eftir að skyldum sem skólinn leggur á herðar foreldranna hefur verið sinnt:

Par sem peim hefur haldist vel á pessar tvær vikur sem liðnar eru pá eru verkefnin frá skólanum búin. Sigríður sest pví niður og býr til nýja stundaskrá. Nýja stundaskráin bíður á borðum barnanna daginn eftir og eru pau heldur hissa pegar pau sjá hana. Í dag er náttúrufræði og munu pau fara í fjöruna til pess, á morgun er sköpun og pá eiga pau að skapa daginn og pað sem er best á stundatöflunni er klukkutími á dag par sem pau mega hringja myndsímtal í vin og spjalla eða leika.

Раð að Sigríður geti hér ekki búið til nýja stundaskrá fyrr en verkefnin frá skólanum eru búin sýnir tangarhald hefðbundinnar skólavinnu á tíma foreldra og barna. Í pessari sögu spilar Sigríður mjög vel úr aðstæðum sínum. Hún sinnir ekki eingöngu hefðbundnu námi barnanna heldur líka óhefðbundnu námi og gerir pað með skipulegum og skapandi hætti. Pannig er óhefðbundið nám í pessari sögu í raun ekki andóf gegn hefðbundnu námi heldur talar inn í pá mynd af hinni hæfu móður að hún sé sífellt að pjálfa barnið sitt til að verða besta útgáfan af sjálfu sér.

Bakgrunnur foreldris, pekking og menntun hefur einnig áhrif á hversu vel pað getur sinnt hlutverki kennara. Nokkrar af sögunum lýsa hversu erfitt söguhetjan á með að setja sig inn í námsefni barnanna. Sjálfsnám foreldra bætist við pau mýmörgu verkefni sem peir purfa að sinna. Peir hafa misjafnar forsendur til að taka við keflinu af kennara barna sinna. Petta skapar pirring og sektarkennd:

Fyrsta daginn sem krakkarnir eru heima vaknar Sigríður full metnaðar og ætlar að koma krökkunum af stað í heimanámi og reyna svo að sinna vinnunni. Morgunninn byrjar ágætlega pó að krakkarnir hafi ekki séð tilganginn í pví að klæða sig en eitt af öðru missa pau polinmæðina. Sigríður pirrar sig á pví að skilja námsefnið ekki nægilega vel og pað fær hana til pess að finnast hún heimsk. Hvað hún vildi að kallinn væri heima sem er mikið betri í stærðfræði en hún! Íslenskan er sem betur fer auðveld.

Sigríður kann samt ekki pessa málfræði og man ekkert hvernig algebrureglurnar virka. Hún hleypur í tölvuna að rifja upp. Reynir sitt besta til að hjálpa en pað er flókið að stíga inn í starf kennarans sem hún skildi hvort eð er aldrei sjálf í grunnskóla.

Petta pema lýsir vel peim hindrunum og lausnum sem foreldrar fundu til að gera heimanámi barna sinna skil. Að vera kennari er ekki hluti af starfslýsingu foreldra sem eru misjafnlega í stakk búnir, bæði vegna stöðu sinnar á vinnumarkaði og eigin menntunarbakgrunns, til pess að sinna heimanámi barna sinna. Рemað lýsir einnig ágætlega hversu vanmetin vinna kennara er pegar ætlast er til að foreldrar gangi í störf peirra heima. Á bak við margar af sögunum má svo greina undirliggjandi kvíða um að foreldrið standi sig ekki í stykkinu við heimanám barnsins og pað gæti ógnað velferð pess síðar meir. 


\section{(3) Bugaðir foreldrar rísa upp gegn óraunhæfum kröfum}

Petta pema tengist hinu fyrra en í nokkrum af peim sögum sem sendar voru inn mátti greina andstöðu gegn óraunhæfum kröfum og par með hinni andstyggilegu bjartsýni (Berlant, 2011) sem haldið er að pegnum nýfrjálshyggjusamfélagsins. Sögurnar gera grein fyrir peim ýmsu áhættupáttum sem foreldrum er ætlað að hafa yfirsýn á vegna mögulegs skaða fyrir barnið. Peir, einkum mæðurnar, eru hins vegar að bugast pví peir geta ekki stöðugt haft augastað á börnum sínum eins og nútímasamfélag virðist gera kröfu um (Furedi, 2001):

Börnin fengu meiri tíma í tölvuleikjum en vanalega en hún var of preytt til að standa fast á peim reglum.

Í nokkrum sögum er söguhetjan karl sem í fyrsta skipti finnur sig í pví hlutverki að purfa að sinna heimanámi barnanna auk vinnu, t.d. vegna pess að maki er í framlínustarfi. Pessari reynslu er lýst sem opinberun, vegna peirrar vinnu sem umönnun barnanna krefst, en einnig á sér stað endurmat söguhetjunnar á eigin getu:

Ólafur hlakkaði fyrst til að takast á við petta krefjandi verkefni - að vinna heima, en jafnframt fá tækifæri til að verja meiri tíma með börnum sínum og fá innsýn í námið peirra. Hann gerði sig digran pegar hann spjallaði við vinina - sagði peim að hann hefði verið svo góður í stærðfræði að pað myndi nú ekki vefjast fyrir honum að hjálpa áttundabekkingnum með jöfnuhneppin. Konan hans hló - en á meðan kveið hún fyrir pessum tímum. Ólafur var svona maður sem bara gerði skemmtilegt. Ef hann eldaði, vaskaði hann ekki upp. Ef hann setti í pvottavél, braut hann ekki upp tauið. Á fyrstu vikunni setti Ólafur inn status á Facebook par sem hann sagðist furða sig á pví hvað við værum mikið að setja börnin okkar í geymslu og að femínistarnir hefðu gengið of langt með pví að skipa börnum í leikskóla allan daginn. Eftir viku langaði Ólaf að kasta bókunum út um gluggann og hengja bangsa í glugganum.

Í textabrotinu er Ólafur fyrst fullur eldmóðs og tilhlökkunar, hann myndi nú léttilega ráða við heimanámið sem jöfnuhneppin kristalla. Við sjáum í brotinu bæði endurmat Ólafs á getu sinni til að sinna börnunum en einnig undirliggjandi ádeilu á hinn óvirka föður sem ekki gerir sér grein fyrir peirri vinnu sem liggur að baki aðstoð við heimanám og öðrum húsverkum. Jafnframt sýnir sagan hvernig sú vinna sem mæður inna oftast af hendi, t.d. að hafa umsjón með heimanámi barna, er iðulega vanmetin (sjá Capellini o.fl., 2019).

Sögurnar undirstrika að pað að njóta samkomubannsins og samveru með fjölskyldunni eru forréttindi peirra sem búa við fjárhagslegt öryggi, starfsöryggi og sveigjanleika í starfi sem einkennir störf millistéttar og efri stéttar (Reay, 1998). Kvíðinn um að standa sig ekki sem foreldri kemur vel í ljós hjá peim sem ekki búa við pessar aðstæður. Foreldri parf að velja á milli eigin heilsu, vinnunnar eða menntunar barnanna:

Рað eina sem Sigríður veit er að petta mun ekki ganga til lengdar. Eitthvað á eftir að láta undan, hvort sem pað er menntun barnanna, vinnan eða geðheilsan.

Andóf felst í pví að söguhetjurnar eru látnar átta sig á að pær eru ekki í aðstæðum til að ná böndum yfir allar pær kröfur sem gerðar eru til peirra. Pær leiða hjá sér hegðun hjá börnum sínum sem í nútímasamfélagi er álitin hættuleg eða skaðleg. Foreldrar slá af kröfum sínum og leyfa barninu að skemmta sér yfir sjónvarpsefni og í tölvuleikjum. Peir geta ekki sinnt hlutverki sínu á tvenns konar vettvangi samtímis. Sjónvarpið og skjárinn eru stundum hjálplegir umönnunaraðilar og gefa barninu einnig tækifæri til pess að verja tíma með félögum sínum. 
Á milli pess sem Sigríður leikur grunnskólakennara svarar hún tölvupóstum og slekkur stafræna elda í vinnunni. Pannig líður dagurinn. Sigríður nær lítilli einbeitingu og börnin eru sjálfala í öllum peim tækjum sem pau komast yfir. Annað barnið fær að fara í skólann. Hleypur út, spennt að losna af heimilinu. Hitt fær að leika sér. Frjáls leikur er ágætur, en með engan leikfélaga og meðvitað um innilokunina pá verður leikurinn heftari. Sigríður kemst á ról í vinnunni. Barnið biður um sjónvarp yfir hádegismatnum. Sigrîður segir já.

Í sögunum benda pátttakendur í rannsókninni á hversu ípyngjandi eftirlits- og skemmtihlutverk foreldra getur verið. Petta er í samræmi við gagnrýni erlendra rannsakenda t.d. Cappellini og félaga (2019):

Mjög góð móðir, en hún er mannleg og finnst erfitt að purfa að sinna börnunum sínum allan sólarhringinn.

Sigríður er góð mamma, sem aðstoðar börnin eins og hún getur. Hún elskar pau mikið en pegar hún er preytt hefur hún minni polinmæði. Hún er byggð á raunverulegri manneskju.

Sigríður er gott foreldri en mannleg. Hún er af vilja gerð og reynir en lætur pað fara í taugarnar á sér ef hlutirnir eru ekki uppá 10 og henni finnst hún vera að missa stjórnina í samkomubanninu.

Eins og sjá má af textabrotunum hér að framan er eins og pátttakendum sé í mun að peir sem lesi sögurnar skilji að pessar kröfur eru raunverulegar og byggi á „raunverulegum aðstæðum“. Foreldrið, yfirleitt móðirin, elskar barnið sitt pó svo hún hafi ekki ávallt augastað á pví. Í textabrotinu hér að neðan er pví lýst hvernig Sigríður skammast sín fyrir að standa sig ekki og missa tökin á heimilinu, náminu og börnunum. Heimilið er allt í óreiðu og engin stjórn á börnunum. Velgengni annarra foreldra er stöðugt til sýnis á samfélagsmiðlum og gerir vanmátt og sektarkennd peirra sem standast ekki pann samanburð ljósan. Eins og McRobbie (2013) bendir á ræður fyrirmyndarmóðirin ekki fullkomlega við öll sín verkefni:

Eftir hádegi ætla pau að halda áfram en krakkarnir missa polinmæðina algjörlega og byrja að rífast. Sigríður fær engan vinnufrið. Kl. 12:30 eru allt húsið í drasli, barnaefni í gangi og bæði börnin í spjaldtölvunum. Pau reyna aftur á morgun hugsar Sigríður á meðan hún skammast sín yfir pví að eiga ekki jafn auðvelt með petta og Anna sem setti inn mynd á samfélagsmiðla fyrr um morguninn og virtist hafa petta allt saman á hreinu - húsið og nám barnanna!

Í sögum sem lýstu bugun foreldra var söguhetjan oft einstætt foreldri eða foreldri sem purfti að sinna fjölskyldu eitt vegna pess að maki var í framlínustarfi eða var óvirkur (yfirleitt feður). Söguhetjurnar í peim sögum gagnrýndu pær kröfur sem gerðar eru til fjölskyldna. Pær miðuðu sig ekki við fyrirmyndarfjölskyldurnar sem skrifa um afrek sín á samfélagsmiðlum heldur settu sér raunhæf markmið. Söguhetjan nær innri ró með pví einfaldlega að sætta sig við óreiðuna og blása á kröfur samfélagsins um fyrirmyndarheimili (Nathanson, 2013). Nýja „óreiðuskipulagið“ er fjölskyldu- og barnvænt:

Pað er meiri friður á heimilinu pegar börnin fá að ráđa tíma sínum sjálf, meðan passað er upp á matartíma og háttatíma. Einhvern veginn finna pau sig í pessu nýja skipulagi. Suma daga fer Úlfhildur meira að segja í brjóstahaldara og málar sig og Ólafur rakar sig og fer úr náttbuxunum. Fjölskyldan finnur nýjan takt og fer að njóta pess að pað sé minna að gera en venjulega. Pau taka stundum fram gömul spil og fá jafnvel börnin til að spila. Pau finna gömul myndaalbúm og skoða saman.

Vikurnar teygjast áfram og skipulagið fallega er komið út í bílskúr. Nú eru allir bara að reyna að lifa af. Hjónin reyna að viðra sig og börnin reglulega, en veðrið er ekki að hjálpa til. Pau leyfa peim að vera allt of mikið í tölvuleikjum og krossa fingur og vona að pað sé eitthvað lærdómsríkt í einhverjum peirra. 
„Skipulagið fallega“ er hér táknmynd fyrir pær kröfur sem fjölskyldan reynir að laga sig að, hefðbundið heimanám, hollur matur og svo framvegis. Pannig eru söguhetjurnar í virkri andstöðu gegn ómanneskjulegum kröfum samfélagsins til peirra sem foreldra (Cappellini o.fl., 2019) og jafnframt orðræðunni um að foreldrar verði að aðstoða börnin við pað nám sem skólinn skilgreinir sem mikilvægt. Söguhetjur horfast í augu við að pær kröfur sem gerðar eru til peirra leiði ekki endilega til hamingjuríkara heimilislífs. Pvert á móti láta pær foreldra finna til vanmáttar. Hamingjuhandrit nýfrjálshyggjunnar (Berlant, 2011) gengur ekki upp fyrir foreldra. Kannski má finna aðrar leiðir til að skilgreina hver „besta útgáfan“ af barninu og foreldrinu er. Hana er ekki að finna hjá úrvinda foreldri og barni.

\section{Lokaorð}

Í pessari grein höfum við gert grein fyrir nokkrum af peim pemum sem birtast í sögulokagögnum um foreldravinnu á tímum heimsfaraldurs og skerts skólastarfs. Áður höfum við fjallað um sömu gögn og meðal annars greint með nánari hætti togstreitu á milli mæðra og feðra og áhrif hugmyndafræði nýfrjálshyggju á heimilislíf (Auður Magndís Auðardóttir og Annadís G. Rúdólfsdóttir, 2020). Pau pemu sem við höfum greint hér hverfast um togstreitu um tímann, glímu foreldra við heimanámið og uppreisn gegn prúgandi kröfum nýfrjálshyggjuvæðingar foreldrahlutverksins. Ljóst er að sögulokin sem pátttakendur skálduðu bera pess merki að hafa orðið til í pjóðfélagi par sem kröfur til útivinnandi foreldra eru miklar og jukust enn á tímum skerts skólastarfs vorið 2020. Athygli vekur að í priðju bylgju faraldursins hérlendis, í október 2020, ákváðu yfirvöld að skerða ekki leik- og grunnskólastarf vegna peirrar miklu röskunar sem pað hefði í för með sér fyrir samfélagið í heild. Pessi röskun var e.t.v. ekki fyrirsjáanleg pegar skólastarf var skert vorið 2020 en reynsla, og m.a. gögn úr pessari rannsókn og rannsókn Andreu Hjálmsdóttur og Valgerðar S. Bjarnadóttur (2020), sýna að hún var veruleg.

Niðurstöður rannsóknar okkar sýna að togstreita um tíma á heimilum barnafjölskyldna er yfir og allt um kring í sögum pátttakenda okkar. Tíminn verður að bitbeini, bæði á milli atvinnu og heimilisstarfa en einnig á milli sambúðaraðila. Petta er í samræmi við erlendar rannsóknir sem sýna að tími og hvernig hann er notaður er kynjapólitískt mál sem snertir kjarna félagslegs réttlætis í pjóðfélaginu. Jafnvel í pjóðfélagi sem telur sig nánast hafa náð fullu kynjajafnrétti er mikill prýstingur á foreldra, einkum mæður, að halda mörgum boltum á lofti án nokkurra hnökra eða yfirsjónar. Foreldrinu getur ekki annað en mistekist og peirri tilhugsun fylgir kvíði og skömm. Slík orðræða er einnig hluti af nýfrjálshyggjuvæðingu sem elur á fullkomnunarhyggju en par verða mæður í millistétt einkum fyrir barðinu (McRobbie, 2013).

Hverri orðræðu fylgir einnig gagn-orðræða par sem meginstraumshugmyndir eru gagnrýndar, gert að peim grín eða pær pagðar í hel. Petta sjáum við einnig í gögnum par sem söguhetjurnar endurskilgreina hlutverk sín sem foreldrar. Í peim sögum ákveða söguhetjurnar að njóta samkomubannsins og pess friðar sem pað færir peim. Ljóst er að slíkt er pó ekki í boði fyrir alla foreldra heldur er eingöngu aðgengilegt peim sem mest auðmagn hafa í formi tíma, áhyggjuleysis, sveigjanleika í vinnu, geðheilsu og líkamlegrar heilsu.

Eins og fram hefur komið voru pað einkum háskólamenntaðar konur sem tóku pátt í rannsókninni. Sögurnar gefa pví fyrst og fremst innsýn í pær orðræður og pá pekkingu sem eru aðgengilegar pessum hópi pegar hann skáldar upp sögur um foreldrahlutverkið á tímum COVID-19. Pað er pessi pekking og pað gildismat sem hún felur í sér sem við höfðum áhuga á að greina. Pað var pó athyglisvert hversu sterkar tilfinningar komu fram í sögunum. Tilfinningarnar voru bæði jákvæðar pegar lýst var ánægju foreldrisins af að ná að standa sig en einnig neikvæðar og pá einkum sem gremja en einnig kvíði. Pessar sterku tilfinningar mætti túlka sem svo að pátttakendur séu í einhverjum tilfellum að vísa í reynslu sem peir pekktu til og virtust tengja við. Áhugavert hefði pó verið að fá betur fram sjónarhorn karla og einstaklinga af lægri stéttum í pessari rannsókn, greina í hvers konar aðstæður pau myndu setja sögupersónuna og hvernig pau tengja við ríkjandi orðræður samfélagsins um hlutverk foreldra pá einkum kröfur um aukna pátttöku karla/feðra í barnauppeldi. 
Niðurstöður okkar gefa til kynna að COVID-19 faraldurinn hafi afhjúpað hversu misvel heimilin eru í stakk búin til að sinna peim miklu kröfum sem gerðar eru til peirra. Við viljum meina að slíkt eigi ekki eingöngu við á tímum heimsfaraldurs og skerts skólastarfs pó pað ástand hafi vissulega ýkt kröfurnar og togstreituna. Foreldravinna, heimilishald og togstreitan um tímann eru kynjapólitísk mál og lykillinn að pví að Ísland færist í átt að auknu jafnrétti kynjanna felst ekki síst í að við berum kennsl á pau sem slík. Til að pað gerist parf að rýna betur í pær orðræður sem hlutverk foreldra eru skilgreind út frá, t.d. af skólakerfinu og vinnumarkaðinum. Рað parf einnig að taka tillit til peirra forsendna sem foreldrar hafa til að koma til móts við pær kröfur sem gerðar eru til peirra, t.d. út frá peirra eigin félagslega bakgrunni og stöðu. Nýfrjálshyggjuorðræðan, sem hampar framtakssemi einstaklingsins og markaðslausnum, skautar yfir pær kerfislægu hindranir sem foreldrar mæta vegna félagslegrar stöðu. Hún lítur einnig framhjá pví hversu sterk ítök hefðbundnar kynjaðar orðræður um foreldrahlutverkið hafa par sem enn virðist pykja sjálfsagt að konur forgangsraði á annan hátt en karlar.

\section{Pakkir}

Við pökkum Háskólasjóði fyrir að styrkja pessa rannsókn.

\section{"The time-plan has been ousted and is now in the garage": Family life and homework in stories about COVID-19}

In Western societies the role of the parent has increasingly been framed by neoliberal discourses. The focus is on the parent, especially the professional middle-class mother, as an entrepreneur who makes choices and trains the child with an eye to how it can maximize its potential and become a good citizen. This places a strain on parents, especially working mothers, who juggle their parenting responsibilities with their work outside the home. The COVID-19 epidemic upset these juggling acts and the fine-tuned daily rhythms of many families. In April, 2020, when the study took place, Iceland was in semi-lockdown, with schools running at limited capacity and a ban of gatherings of more than 20 people. Furthermore, many parents did not have access to their usual support in terms of childcare. These times without "precedent" thus provided an interesting moment to explore constructions of parenting, especially in relation to parents' role in their children's education and how at times contradictory demands from the home and work were met.

This article adopts a feminist poststructuralist perspective to analyse ideas about parenting roles in relation to children's homework during the COVID-19 epidemic in Iceland. Data was collected using the story-completion method during the period April 7-24, 2020, when a national emergency had been declared in Iceland because of the Corona virus. The story completion method is useful as it provides insight into the sociocultural ideas and discourses people draw on when making sense of a topic. The participants were approached on social media where they were provided with a link directing them to the task on Qualtrics. There the participants were randomly presented with either of two different story stems and asked to complete a story. In the first story stem the main fictional character is a mother who is informed that her children will only be able to stay 2 hours per day at school and she is sent ideas for homework to work on with her children. The other story stem is identical except the main character is a father. In total, 97 stories were collected. The majority of the participants who submitted stories were middle-class, university-educated women and the stories have to be interpreted with that in mind. However, they are an interesting group as they are usually considered to set the norm for good mothering. A recurrent idea running through all the stories 
we collected was how parents tackled the many demands placed on them and how parental excellence was defined either in alignment with or in resistance to the dominant neoliberal discourse. The analysis resulted in 3 themes: (1) Finding the time: In this theme time is defined as a gendered resource where mothers experience more demands on their time. Lack of time calls for management skills as revealed, for example, in the making of detailed schedules and time-plans for all family members where each task is listed and organized. (2) The struggle with homework: Re-evaluation, success and failures. The parents' social status, for example level of education and marital status, plays a part in how realistic it is for them to supervise their child's homework. The parent who fails experiences feelings of guilt and shame. The parent who succeeds often does so at the expense of vital time for paid work. (3) Overburdened parents resist unrealistic demands. This theme describes how parents in the stories are made to question the neoliberal ideas that good parenting entails a constant awareness of risks to the child and its development. The stories describe the pleasure taken in untidy homes and education that does not follow the school curriculum but rather the rhythm of the home. Overall, the themes shed important light on the pressures parents face in modern society and their anxious investment in discourses of parenting where they feel their children's and their own well-being is on the line. They also pinpoint how important it is to place unrealistic demands on parents in a social and discursive perspective rather than framing them as the responsibility of already overburdened parents. Only by doing so can we work towards social justice and equality in our society.

Key words: Parenting, homework, neoliberalism, COVID-19, story-completion method

\section{Um höfunda}

Annadís Greta Rúdólfsdóttir (annadis@hi.is) er dósent í aðferðafræði rannsókna við Menntavísindasvið Háskóla Íslands. Hún lauk BA-prófi í sálfræði frá Háskóla Íslands 1989, MSc-gráðu í félagssálfræði frá London School of Economics and Political Science árið 1990 og loks doktorsgráðu frá sama skóla í félagssálfræði árið 1997. Rannsóknasvið hennar snúa að mótun kyngervis ungmenna og móðurhlutverkinu.

Auður Magndís Auðardóttir (ama@hi.is) er aðjúnkt ogdoktorsnemiviðMenntavísindasvið Háskóla Îslands. Sérpekking hennar og rannsóknir snúa meðal annars að kynjafræði, hinseginfræði og félagsfræði menntunar með áherslu á stétt, skólaval og markaðshyggju.

\section{About the authors}

Annadís Greta Rúdólfsdóttir (annadis@hi.is) is an Associate Professor in Research Methodology in the School of Education at the University of Iceland. She completed a BA in Psychology from the University of Iceland in 1989, an MSc in Social Psychology from the London School of Economics in 1990 and a PhD in Social Psychology from the same school in 1997. Her research has focused on constructions of gender, youth and motherhood.

Auður Magndís Auðardóttir (ama@hi.is) is an adjunct lecturer and a $\mathrm{PhD}$ candidate at the School of Education, University of Iceland. Her research interests involve gender studies, queer studies and sociology of education with an emphasis on class, school choice and marketization. 


\section{Heimildir}

Andrea Hjálmsdóttir og Valgerður S. Bjarnadóttir. (2020). "I have turned into a foreman here at home”: Families and work-life balance in times of COVID-19 in a gender equality paradise. Gender, Work and Organization. doi:10.1111/gwao.12552

Auður Magndís Auðardóttir og Annadís G. Rúdólfsdóttir. (2020). “Chaos ruined the children’s sleep, diet and behaviour": Gendered discourses on family life in pandemic times. Gender, Work and Organization. doi:10.1111/gwao.12519

Auður Magndís Auðardóttir og Berglind Rós Magnúsdóttir. (2020). Even in Iceland? Exploring mothers' narratives on neighbourhood choice in a perceived classless and feminist utopia. Children's Geographies. do i: $10.1080 / 14733285.2020 .1822515$

Auður Magndís Auðardóttir og Kosunen, S. (2020). Choosing private compulsory schools: A means for class distinctions or responsible parenting? Research in Comparative and International Education, 15(2), 97-115.

Ásta Jóhannsdóttir. (2018). Gender identities in gender equal Iceland: Possibilities and limitations in the performance of gender among young people in Reykjavík 2012-2016 (oútgefin doktorsritgerð). Háskóli Íslands, Reykjavík.

Ball, S. J., Bowe, R. og Gewirtz, S. (1996). School choice, social class and distinction: The realization of social advantage in education. Journal of Education Policy, 11(1), 89-112. doi:10.1080/0268093960110105

Barnaverndarstofa. (2020, 3. nóvember). Greining á tölulegum upplýsingum frá barnaverndarnefndum. Sótt af https:/www.bvs.is/tolfraedi-og-utgefid-efni/frettir/frettasafn/greining-a-tolulegum-upplysingum-frabarnaverndarnefndum-1

Berglind Rós Magnúsdóttir, Auður Magndís Auðardóttir og Kolbeinn Stefánsson. (2020). Dreifing efnahags- og menntunarauðs meðal foreldra í skólahverfum höfuðborgarsvæðisins 1997-2016. Stjórnmál og stjórnsýsla, 16(2), 285-308. doi:10.13177/irpa.a.2020.16.2.10

Berlant, L. (2011). Cruel optimism. Durham: Duke University Press.

Binkley, S. (2014). Happiness as enterprise. An essay on neoliberal life. Albany: State University of New York Press.

Braun, V. og Clarke, V. (2006). Using thematic analysis in psychology. Qualitative Research in Psychology, 3(2), 77-101. doi:10.1191/1478088706qp063oa

Braun, V. og Clarke, V. (2020). One size fits all? What counts as quality practice in (reflexive) thematic analysis? Qualitative Research in Psychology, 1-25. doi:10.1080/14780887.2020.1769238

Braun, V., Clarke, V., Hayfield, N., Frith, H., Malson, H., Moller, N. og Shah-Beckley, I. (2019). Qualitative story completion: Possibilities and potential pitfalls. Qualitative Research in Psychology, 16(1), 136-155. do i: 10.1080/14780887.2018.1536395

Byrne, B. (2006). In search of a 'good mix': 'Race', class, gender and practices of mothering. Sociology: The Journal of the British Sociological Association, 40(6), 1001-1017. doi:10.1177/0038038506069841

Cabanas, E. og Illouz, E. (2019). Manufacturing happy citizens: How the science and industry of happiness control our lives. Cambridge: Polity Press.

Cappellini, B., Harman, V., Marilli, A. og Parsons, E. (2019). Intensive mothering in hard times: Foucauldian ethical self-formation and cruel optimism. Journal of Consumer Culture, 19(4), 469-492. doi:10.1177/1469540519872067

Clarke, V., Hayfield, N., Moller, N. og Tischner, I. (2017). Once upon a time ... Qualitative story completions. Í V. Braun, V. Clarke og D. Gray (ritstjórar), Collecting qualitative data: A practical guide to textual, media and virtual techniques (bls. 45-71). Cambridge: Cambridge University Press.

Furedi, F. (2001). Paranoid parenting: Abandon your anxieties and be a good parent. London: Allen Lane.

Gewirtz, S. (2001). Cloning the Blairs: New Labour's programme of the re-socialization of working-class parents. Journal of Education Policy, 16(4), 365-378.

Gillies, V. (2007). Marginalised mothers: Exploring working-class experiences of parenting. London: Routledge.

Guðbjörg Linda Rafnsdóttir og Ólöf Júlíusdóttir. (2018). Reproducing gender roles through virtual work: The case of senior management. International Journal of Media \& Cultural Politics, 14(1), 77-94. doi:10.1386/ macp.14.1.77_1 
Guðný Gústafsdóttir. (2016). Mediated through the mainstream: Image(s) of femininity and citizenship in contemporary Iceland 1980-2000 (oútgefin doktorsritgerð). Háskóli Íslands, Reykjavík.

Gyða Margrét Pétursdóttir. (2009). Within the aura of gender equality: Icelandic work cultures, gender relations and family responsibility: A holistic approach (oútgefin doktorsritgerð). Háskóli Íslands, Reykjavík.

Helgøy, I. og Homme, A. (2017). Increasing parental participation at school level: A 'citizen to serve' or a 'customer to steer'? Nordic Journal of Studies in Educational Policy, 3(2), 144-154. doi:10.1080/20020317 .2017 .1343625

Holloway, S. L. og Pimlott-Wilson, H. (2014). "Any advice is welcome isn't it?": Neoliberal parenting education, local mothering cultures, and social class. Environment and Planning A: Economy and Space, 46(1), 94-111. doi:10.1068/a45457

Hutchison, K. (2012). A labour of love: Mothers, emotional capital and homework. Gender and Education, 24(2), 195-212. doi:10.1080/09540253.2011.602329

Ingvar Pór Björnsson. (2020, 24. apríl). Um 30\% fleiri tilkynningar um heimilisofbeldi. RÚV. Sótt af https:// www.ruv.is/frett/2020/04/24/um-30-fleiri-tilkynningar-um-heimilisofbeldi

Kristín Jónsdóttir. (2013). Desirable parental participation in activities in compulsory schools. Barn, 4, 29-44. doi:10.1108/GM-03-2017-0028

Lee, E., Bristow, J., Faircloth, C. og Macvarish, J. (2014). Parenting culture studies. London: Palgrave Macmillan.

Livingstone, S. (2017, 5. desember). The evidence of the risk to children online. Sótt af https://blogs.lse.ac.uk/ medialse/2017/12/05/making-the-internet-a-safer-and-better-place-for-children/

Livingstone, S. og Sefton-Green, J. (2016). The class living and learning in the digital age. New York: New York University Press.

Macvarish, J. (2014). The politics of parenting. Í E. Lee, J. Bristow, C. Faircloth og J. Macvarish (ritstjórar), Parenting culture studies (bls. 76-102). London: Palgrave Macmillan.

McRobbie, A. (2009). The aftermath of feminism: Gender, culture and social change. London: Sage.

McRobbie, A. (2013). Feminism, the family and the new 'mediated' maternalism. New Formations, 80, 119137. doi.org/10.3898/newF.80/81.07.2013

Nathanson, E. (2013). Television and postfeminist housekeeping: No time for mother. New York: Routledge.

OECD. (e.d.). Employment: Labour force participation rate, by sex and age group. Sótt af https://stats.oecd. org/index.aspx?queryid $=54741$

Oksala, J. (2013). Feminism and neoliberal governmentality. Foucault Studies, (16), 32-53. doi:10.22439/ fs.v0i16.4116

Olmedo, A. og Wilkins, A. (2016). Governing through parents: A genealogical enquiry of education policy and the construction of neoliberal subjectivities in England. Discourse: Studies in the Cultural Politics of Education, 38(4), 573-589.

Orgid, S. (2019). Heading home: Motherhood, work and the failed promise of equality. New York: Columbia University Press.

Ólöf Júlíusdóttir, Guðbjörg Linda Rafnsdóttir og Porgerður J. Einarsdóttir. (2018). Top managers and the gendered interplay of organizations and family life: The case of Iceland. Gender in Management: An International Journal, 33(8), 602-622.

Reay, D. (1998). Class work: Mothers' involvement in their children's primary schooling. London: UCL Press.

Reay, D. (2017). Miseducation: Inequality, education and the working classes. Bristol: Policy Press.

Reay, D. (2020). The perils and penalties of meritocracy: Sanctioning inequalities and legitimating prejudice. The Political Quarterly, 91(2), 405-412. doi:10.1111/1467-923X.12829

Rose, N. (1989). Governing the soul: The shaping of the private self. London: Routledge.

Skeggs, B. og Wood, H. (2012). Reacting to reality television: Performance, audience and value. London: Routledge.

Sólveig Sigurðardóttir og Annadís G. Rúdólfsdóttir. (2019). „Pessi týpíska óörugga stelpa“: Greining á sögum ungra kvenna um holdafar og stefnumót. Netla - Veftimarit um uppeldi og menntun. Sótt af https://netla. hi.is/greinar/2019/ryn/13.pdf 
Staub, M. og Guðbjörg Linda Rafnsdóttir. (2020). Gender, agency, and time use among doctorate holders: The case of Iceland. Time \& Society, 29(1), 143-165. doi:10.1177/0961463x19884481

Terry, G., Hayfield, N., Clarke, V. og Braun, V. (2017). Thematic analysis. Í C. Willig og W. Stainton Rogers (ritstjórar), The Sage handbook: Qualitative research in psychology. London: Sage.

Vincent, C. (2017). 'The children have only got one education and you have to make sure it's a good one': Parenting and parent-school relations in a neoliberal age. Gender and Education, 29(5), 541-557. doi:10. 1080/09540253.2016.1274387

Walkerdine, V. og Lucey, H. (1988). Democracy in the kitchen: Regulating mothers and socialising daughters. London: Virago.

Walkerdine, V., Lucey, H. og Melody, J. (2001). Growing up girl. Psychosocial explorations of gender and class. Hampshire: Palgrave.

Porgerður J. Einarsdóttir. (2020). All that glitters is not gold: Shrinking and bending gender equality in rankings and nation branding. NORA - Nordic Journal of Feminist and Gender Research, 28(2), 140-152. doi:1 $0.1080 / 08038740.2020 .1745884$

Annadís Greta Rúdólfsdóttir og Auður Magndís Auðardóttir. (2020). Skipulagið er komið út í bílskúr: Fjölskyldulíf, heimanám og COVID-19 Netla - Veftímarit um uppeldi og menntun: Sérrit 2020 - Menntakerfi og heimili á tímum COVID-19 Sótt af http://netla.hi.is/serrit/2020/menntakerfi_heimili_covid19/12.pdf DOI: https://doi.org/10.24270/serritnetla.2020.17 
Netla - Veftímarit um uppeldi og menntun:

Sérrit 2020 - Menntakerfi og heimili á tímum COVID-19 